\title{
QUANTITATIVE ANALYSIS ON DETERIORATION AND REMAINING LIFE OF STEEL BRIDGE PAINTING BASED ON FIELD DATA
}

\author{
Hiroshi FUJIWARA ${ }^{1}$ and Masaru MIYAKE ${ }^{2}$ \\ ${ }^{1}$ Tokorozawa Operation Office, Tokyo Operation Bureau, Japan Highway Public Corporation \\ (761-1, Sakanoshita, Tokorozawa-shi, Saitama, 359-0012, Japan) \\ ${ }^{2}$ Second Construction Division, Hokkaido Regional Bureau, Japan Highway Public Corporation \\ (5-12-30, Ohyachi-Nishi, Atsubetsu-Ward, Sapporo, 004-8512, Japan)
}

\begin{abstract}
With the results of field investigations and outdoor exposure experiments of painted specimens, time-lapse deterioration of paintings was statistically analyzed by using "Automatic Evaluation System for Paint Film Deterioration" in order to establish deterioration curves logically. Quadratic curves were found to be well fitted to the paint film deterioration within the practical period of 10 to 20 years. Estimation curves were established for three corrosive environments such as mild environment, seashore environment, and tropical environment (hot and highly humid).
\end{abstract}

Key Words : steel bridge, paint film deterioration ratio, image processing system, estimating remaining life, deterioration model, corrosion depth

\section{INTRODUCTION}

Although paintings are widely used for corrosion protection of steel bridges, periodical repainting is required throughout bridge's lifespan to maintain its performance. The painting area of the steel bridge in our country is about $40,000,000$ sq. $\mathrm{m}$ and about $3,000,000$ sq. $\mathrm{m}$ is repainted among these every year. ${ }^{1)}$ The steel bridge repaintings are repeated in about 10 years in a mild environment on the average. ${ }^{2)}$ Moreover, the repainting area and the repainting cost keep increasing every year because steel bridge asset increases. $^{1)}$

The remaining life estimation of the paint film is important to execute repainting of the steel bridge efficiently. Though visual observation is mainly applied for current inspection of steel bridge paintings, quantitative evaluation on paint film deterioration is quite difficult due to individual errors occurred from each inspector. A quantitative evaluation of the paint film deterioration by a

This paper is translated into English from the Japanese paper, which originally appeared on J, Struct, Mech, Earthquake Eng., JSCE, №. 696/ I -58, pp.111-123, 2002.1. scientific technique is necessary and indispensable to improve the accuracy of the longevity forecast. Therefore, " Paint film deterioration degree diagnosis system " was developed, which evaluates the degree of paint film deterioration quantitatively by photos with applying the image processing technology. ${ }^{3)}$

Feasibility studies have been conducted by using " Paint film deterioration degree diagnosis system ". Results of field investigations for 624 steel bridges and results of exposure tests for painted specimens at Tokyo, Hokuriku, and Okinawa have been analyzed by the diagnosis system. Paint film deteriorations were quantitatively analyzed and closely resembled to logistic curves on several corrosive environments, and finally, remaining life of paint film on each steel bridges is estimated.

\section{DETERIORATION TENDENCY OF STEEL BRIDGE PAINT FILM BY THE FIELD INVESTIGATION DATA}

\section{(1) Field investigation}

Seven environments (the Rural, the ravine, mountains, the residential quarter, the intersection 
Table 1 Details of investigated bridge

\begin{tabular}{|c|c|c|c|c|c|c|c|c|c|c|c|c|c|c|c|c|c|c|c|c|}
\hline \multirow[b]{2}{*}{ Expressway } & \multirow[b]{2}{*}{ 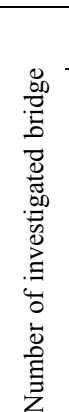 } & \multicolumn{6}{|c|}{$\begin{array}{l}\text { Main environment } \\
\text { at Bridge location }\end{array}$} & \multicolumn{5}{|c|}{ Bridge type } & \multicolumn{3}{|c|}{$\begin{array}{c}\text { Coating } \\
\text { System } \\
\end{array}$} & \multicolumn{5}{|c|}{ Number of investigated data } \\
\hline & & 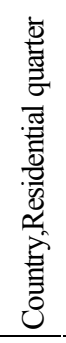 & 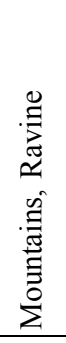 & 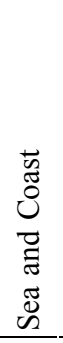 & 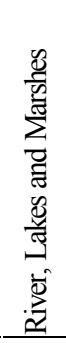 & 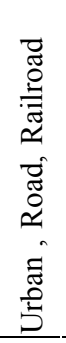 & 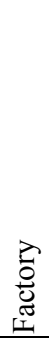 & 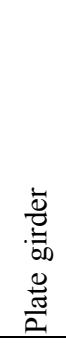 & 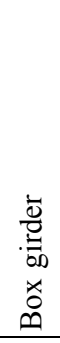 & $\stackrel{\infty}{E}$ & 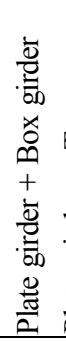 & 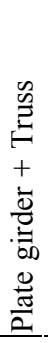 & A & $\mathrm{B}$ & C & 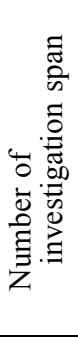 & 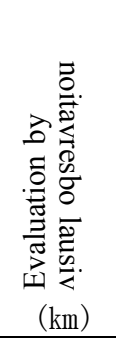 & 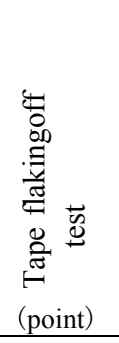 & 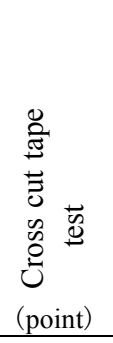 & 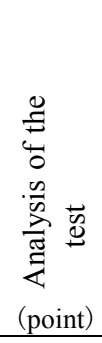 \\
\hline Douo & 65 & 28 & 5 & 24 & & 8 & & 50 & 8 & 1 & 5 & 1 & 41 & 24 & & 5 & 10.803 & 1178 & 120 & 6 \\
\hline Sapporo & 9 & & 4 & 2 & & 3 & & 8 & & & & 1 & 8 & 1 & & 1 & 1.784 & 77 & 76 & 3 \\
\hline Tohoku & 62 & 25 & 17 & & 19 & 1 & & 51 & 10 & & 1 & & 55 & 7 & & 3 & 8.001 & 484 & 132 & 6 \\
\hline Jouban & 14 & 5 & 2 & & 7 & & & 14 & & & & & 9 & 5 & & 1 & 3.898 & 388 & 40 & 2 \\
\hline Tomei & 59 & 16 & 17 & 1 & 20 & 5 & & 59 & & & & & 56 & 1 & 2 & 4 & 7.979 & 1859 & 431 & 21 \\
\hline Higashi Kanto & 9 & 6 & & & 2 & 1 & & 7 & 1 & & 1 & & 9 & & & 1 & 2.922 & 322 & 52 & 2 \\
\hline Chuo & 80 & 24 & 18 & & 24 & 14 & & 72 & 3 & & 5 & & 78 & & 2 & 7 & 11.539 & 1490 & 210 & 10 \\
\hline Kanetu & 7 & 2 & & & 4 & 1 & & 6 & 1 & & & & 4 & 3 & & & 1.612 & 146 & & \\
\hline Hokuriku & 48 & 18 & 1 & & 28 & 1 & & 45 & 3 & & & & 41 & 6 & 1 & 3 & 8.158 & 751 & 176 & 8 \\
\hline Meishin & 18 & 5 & & & 9 & 4 & & 13 & 4 & & 1 & & 15 & & 3 & & 1.790 & 272 & 56 & 2 \\
\hline Higashi Maihan & 8 & 4 & & & 4 & & & 8 & & & & & 8 & & & & 1.381 & 348 & 64 & 1 \\
\hline Ise & 3 & 3 & & & & & & 3 & & & & & 3 & & & & 0.221 & 48 & 24 & 1 \\
\hline Tokai-Hokuriku & 4 & 1 & & & 3 & & & 2 & 2 & & & & 4 & & & & 0.342 & 56 & 40 & 2 \\
\hline Kinki & 5 & & & & & & 5 & 5 & & & & & & & 5 & & 0.353 & 64 & 24 & 1 \\
\hline Nishi Meihan & 6 & 4 & & & & 2 & & 6 & & & & & 6 & & & & 0.297 & 48 & 8 & 4 \\
\hline Hanwa & 2 & 1 & 1 & & & & & 1 & 1 & & & & 2 & & & & 0.158 & 16 & & 6 \\
\hline Maizuru & 2 & & 1 & & 1 & & & 2 & & & & & 2 & & & & 0.279 & 32 & & \\
\hline Chugoku & 40 & 2 & 9 & & 24 & 5 & & 39 & 1 & & & & 40 & & & 2 & 4.727 & 500 & 116 & 58 \\
\hline Sanyo & 18 & 2 & 4 & & 9 & 3 & & 17 & 1 & & & & 18 & & & & 2.151 & 208 & 88 & 42 \\
\hline Santo Kurashik & 1 & & & & & 1 & & 1 & & & & & 1 & & & & 0.036 & 4 & 4 & 2 \\
\hline Hiroshima & 3 & & & & 3 & & & 3 & & & & & 3 & & & & 0.511 & 48 & 12 & 6 \\
\hline Kyusyu & 17 & 4 & 2 & & 11 & & & 16 & 1 & & & & 17 & & & & 1.332 & 160 & 24 & 12 \\
\hline Miyazaki & 8 & 2 & 1 & & 5 & & & 6 & 2 & & & & 8 & & & & 0.832 & 84 & 26 & 18 \\
\hline Nagasaki & 7 & 3 & 2 & 1 & 1 & & & 6 & 1 & & & & 6 & 1 & & & 0.729 & 64 & 24 & 12 \\
\hline Okinawa & 2 & & & 2 & & & & & 2 & & & & & 2 & & & 0.350 & 44 & 12 & 6 \\
\hline Keiyo & 6 & & & & & 6 & & 6 & & & & & 4 & 2 & & 1 & 2.724 & 344 & 32 & 16 \\
\hline Chiba Togane & 2 & 1 & & & & 1 & & 2 & & & & & 2 & & & & 0.424 & 52 & & \\
\hline Nikkou Utsunomiya & 2 & & 2 & & & & & 1 & 1 & & & & 2 & & & & 0.258 & 28 & 8 & 4 \\
\hline Shin Tone & 2 & 1 & & & 1 & & & & 1 & & 1 & & 2 & & & & 1.103 & 68 & & \\
\hline Kainan Yuasa & 2 & & & & 2 & & & 1 & 1 & & & & 2 & & & & 0.178 & 20 & 8 & 4 \\
\hline Keiji & 2 & & 1 & & 1 & & & 1 & 1 & & & & 2 & & & & 0.486 & 36 & & \\
\hline Oinosaka Kameoka & 1 & 1 & & & & & & 1 & & & & & 1 & & & & 0.116 & 12 & & \\
\hline Daini Shinmei & 3 & 1 & 1 & & & 1 & & 3 & & & & & 3 & & & & 0.261 & 32 & 4 & 2 \\
\hline Himeji & 1 & & & & & 1 & & 1 & & & & & 1 & & & & 0.085 & 12 & & \\
\hline Taishi Tathuno & 1 & 1 & & & & & & & 1 & & & & 1 & & & & 0.095 & 12 & & \\
\hline Hiroshima Kure & 1 & & & 1 & & & & & 1 & & & & & 1 & & & 1.015 & 44 & & \\
\hline Kanmon & 13 & 1 & 2 & 2 & & 7 & 1 & 13 & & & & & 9 & & 4 & 1 & 2.398 & 399 & 39 & 20 \\
\hline Daisan Keihin & 14 & & & & & 14 & & 12 & 1 & & 1 & & 13 & & 1 & 1 & 2.880 & 316 & 312 & 157 \\
\hline Yokahama Shindo & 11 & & & & & 11 & & 6 & 2 & & 3 & & 8 & & 3 & & 1.422 & 24 & 24 & 12 \\
\hline Yokohama Yokosuka & 21 & 12 & 6 & & & 3 & & 18 & 2 & & 1 & & 21 & & & 1 & 3.512 & 104 & 56 & 28 \\
\hline Odawara Athugi & 19 & 12 & 7 & & & & & 18 & & & 1 & & 19 & & & 2 & 3.014 & 426 & 57 & 25 \\
\hline Seishou & 8 & 1 & & $\overline{6}$ & & 1 & & 4 & 2 & & 2 & & & 8 & & 1 & 2.343 & 223 & 209 & 110 \\
\hline Manazuru & 1 & & 1 & & & & & 1 & & & & & 1 & & & & 0.020 & & & \\
\hline Fujimiya & 1 & 1 & & & & & & 1 & & & & & 1 & & & & 0.031 & 4 & 4 & 2 \\
\hline Nishi Fuji & 1 & 1 & & & & & & 1 & & & & & 1 & & & & 0.089 & & & \\
\hline Fujieda & 4 & 4 & & & & & & 4 & & & & & 4 & & & & 0.489 & 11 & & \\
\hline Kakegawa & 2 & 2 & & & & & & 2 & & & & & 2 & & & & 0.066 & & & \\
\hline Iwata & 9 & 9 & & & & & & 9 & & & & & 9 & & & & 0.252 & & & \\
\hline Total & 624 & 203 & 104 & 39 & 178 & $\overline{94}$ & 6 & 545 & 54 & 1 & 22 & 2 & 542 & 61 & 21 & 49 & 95.446 & 10858 & 2512 & 1248 \\
\hline
\end{tabular}

$(※)$ A coating syst :lead ticorrosive paint / kyd resin paint, B coating system:lead anticorrosive paint / chlorinated rubber paint, $\mathrm{C}$ coating system :zinc rich aint / chlorinated rubber paint 
Table 2 Investigation location, investigation item, and investigation frequency

\begin{tabular}{|c|c|c|c|c|c|}
\hline & & & : Enfol & rcement of & the investigated \\
\hline $\begin{array}{l}\text { Bridge } \\
\text { form }\end{array}$ & Investigation locati & on and investigation frequency & $\begin{array}{c}\text { Exvaluation } \\
\text { by visual } \\
\text { observation }\end{array}$ & $\begin{array}{c}\text { Adhesion } \\
\text { test } \\
(※)\end{array}$ & $\begin{array}{l}\text { Analysis of Paint } \\
\text { film adhesion } \\
\text { material }\end{array}$ \\
\hline & Web plate & Outside of outside girder & $\bigcirc$ & $\bigcirc$ & $\bigcirc$ \\
\hline $\begin{array}{l}\text { Plate } \\
\text { girder }\end{array}$ & & $\begin{array}{l}\text { Inside of outside girder, Inside girder } \\
\text { (Edge }: 2 \text { point, Center }: 1 \text { point })\end{array}$ & & & \\
\hline & Flange plate & Lower side of lower flange & $\bigcirc$ & $\bigcirc$ & $\bigcirc$ \\
\hline & & $\begin{array}{l}\text { Lower side of upper flange } \\
\text { (Edge }: 2 \text { point, Center : } 1 \text { point) }\end{array}$ & & & \\
\hline & Stringer (Plate) & Edge $: 2$ point, Center : 1 point & $\bigcirc$ & & \\
\hline & Cross-frame, Lateral & Supporting point : 1 point, Center : 1 point & $\bigcirc$ & & \\
\hline & Web plate, Lower flange plate & Edge $: 2$ point, Center $: 1$ point & $\bigcirc$ & $\bigcirc$ & $\bigcirc$ \\
\hline $\begin{array}{l}\text { Box } \\
\text { girder }\end{array}$ & Inside in box girder bridge & $\begin{array}{l}\text { Upper side of lower flange }: 2 \text { point } \\
\text { Web plate }: 1 \text { point }\end{array}$ & $\bigcirc$ & & \\
\hline & Stringer, Cross beam, Bracket & Edge : 2 point, Center : 1 point & $\bigcirc$ & & \\
\hline
\end{tabular}

(※) The adhesion test means the tape flaking off test and cross-cut tape test.

road, Public road adjacent, the river, lakes and marshes, the factory, and the sea and coast) were specified to cover all environments of steel bridge locations and 624 bridges from Hokkaido to Okinawa were selected as shown in Table 1.

Three investigations were conducted, such as visual observations, adhesion examinations, and analyze of the paint film adhesion material by using "Steel bridge paint film investigation indicator" of "JH maintenance standard" 4) and Japanese Steel Structural Societies. ${ }^{5)}$ Because the content of these investigation results was huge, the visual observation results are mainly analyzed in this paper. The investigation was conducted by the inspectors belonged to 93 Operation Offices of JH (Japan Highway). Afterward, other engineers, specialized in investigating painting by using the diagnosis system, took pictures and analized the pictures by the diagnosis system in order to cancel the individual errors occurred from inspectors' individual subjectivities and different experiences. The investigation location, the investigation item, and the investigation frequency are shown in Table 2.

Deterioration degrees are determined by chart 3 to chart 6 indicated below following 4 deterioration phenomenon; total area of the rust, peeling off, crack, chalking. Definition of each deterioration phenomena and meaning of evaluation rate are described as follows 6) :

(1) Evaluation rate of rust

Because the rust seen on the surface of the paint film means the steel material corrodes under the paint film, this phenomena means crucial and fatal defect. JH judges repainting time of steel bridges when rust area reaches about $3 \%$.
Table 3 Evaluation Grades for rust ${ }^{4}$ )

\begin{tabular}{cl}
\hline Points & \multicolumn{1}{c}{ State of paint film } \\
\hline 40 & Rust is seen in 3\% or more of the investigation area. \\
\hline 30 & $\begin{array}{l}\text { Rust is seen from 1 to less than 3\% of the investiga- } \\
\text { tion area. }\end{array}$ \\
\hline 20 & $\begin{array}{l}\text { Rust is seen from } 0.3 \text { to less than } 1 \% \text { of the investi- } \\
\text { gation area. }\end{array}$ \\
\hline 10 & $\begin{array}{l}\text { Rust is seen from } 0.1 \text { to less than } 0.3 \% \text { of the inves- } \\
\text { tigation area. }\end{array}$ \\
\hline 0 & Abnormality is not seen in the paint film. \\
\hline
\end{tabular}

Table 4 Evaluation Grades for peeling off 4)

\begin{tabular}{cl}
\hline Points & \multicolumn{1}{c}{ State of paint film } \\
\hline 30 & $\begin{array}{l}\text { Peeling off is seen in 33\% or more of the investiga- } \\
\text { tion area. }\end{array}$ \\
\hline 24 & $\begin{array}{l}\text { Peeling off is seen from } 16 \text { to less than } 33 \% \text { of the } \\
\text { investigation area. }\end{array}$ \\
\hline 18 & $\begin{array}{l}\text { Peeling off is seen from } 10 \text { to less than } 16 \% \text { of the } \\
\text { investigation area. }\end{array}$ \\
\hline 12 & $\begin{array}{l}\text { Peeling off is seen from } 3 \text { to less than } 10 \% \text { of the } \\
\text { investigation area. }\end{array}$ \\
\hline 6 & $\begin{array}{l}\text { Peeling off is seen in less than } 3 \% \text { of the investiga- } \\
\text { tion area. }\end{array}$ \\
\hline 0 & Abnormality is not seen in the paint film. \\
\hline
\end{tabular}

Table 5 Evaluation Grades for crack ${ }^{4)}$

\begin{aligned} & \hline Points \multicolumn{1}{c}{ State of paint film } \\ & \hline 10 The crack is remarkable. \\ & \hline 5 The crack occurs. \\ & \hline 0 Abnormality is not seen in the paint film. \\ & \hline\end{aligned}

Table 6 Evaluation Grades for chalking 4)

\begin{tabular}{cl}
\hline Points & \multicolumn{1}{c}{ State of paint film } \\
\hline 10 & $\begin{array}{l}\text { An initial painting color cannot be remarkably pre- } \\
\text { sumed like white compared with initial }\end{array}$ \\
\hline 5 & $\begin{array}{l}\text { Most is considerably changeless though an initial } \\
\text { painting color can be presumed compared with ini- } \\
\text { tial as white. }\end{array}$ \\
\hline 0 & Abnormality is not seen in the paint film. \\
\hline
\end{tabular}


Table 7 Composition of the investigation data according to environment

\begin{tabular}{lrrrrrrrr}
\hline \multirow{2}{*}{$\begin{array}{c}\text { Environments at } \\
\text { bridge location }\end{array}$} & \multicolumn{2}{c}{ Total of data } & \multicolumn{6}{c}{ Data breakdown according to coating system } \\
\cline { 2 - 10 } & \multicolumn{1}{c}{ Total } & Ratio $(\%)$ & \multicolumn{1}{c}{ A } & Ratio $(\%)$ & B & Ratio $(\%)$ & C & Ratio $(\%)$ \\
\hline Rural, Ravine & 21930 & 30.4 & 19701 & 31.0 & 1370 & 22.6 & 462 & 17.6 \\
\hline Residential quarter & 7990 & 11.1 & 6773 & 10.7 & 0 & - & 0 & - \\
\hline Intersection road & 8170 & 11.3 & 7358 & 11.6 & 87 & 1.4 & 22 & 0.8 \\
\hline Public road adjacent & 12069 & 16.7 & 11419 & 18.0 & 411 & 6.8 & 1787 & 67.9 \\
\hline River & 20016 & 27.8 & 18182 & 28.7 & 815 & 13.4 & 0 & - \\
\hline Factory & 885 & 1.2 & 0 & - & 0 & - & 361 & 13.7 \\
\hline Sea and Coast & 1066 & 1.5 & 0 & - & 3378 & 55.8 & 0 & - \\
\hline \multicolumn{1}{c}{ Total } & 72126 & 100 & 63433 & 100 & 6061 & 100 & 2632 & 100 \\
\hline
\end{tabular}

Note) Besides, the data of the unmeasurement is 3455 .

Therefore, after inspection, all steel bridges maintained by $\mathrm{JH}$ are divided into 5 groups described in table 3 and this categorization contributes to determine long-term repainting plan for huge number of steel bridge assets.

(2) Evaluation rate of peeling off (flaking off)

Peeling off of the paint film means the decrease of paint film thickness or even disappearance of paint film. Moreover, peeling off has huge influence on external appearance of bridges. Thus, peeling off sometimes requires immediate repainting. According to the Repainting Standard of $\mathrm{JH}$, steel bridges are repainted when more than $1 / 3$ $(33 \%)$ of their external surfaces are found to be peeling off.

(3) Evaluation rate of crack

Paint film crack easily deteriorates into flaking off or rust though the crack itself is not a serious defect. Therefore, the crack must not be ignored as paint film defect. The crack of the paint film progresses from surface crack to deep one, and deep crack usually accompanies peeling off and rust. Therefore, surface crack is counted as beginning of other deterioration phenomenon.

(4) Evaluation rate of chalking

Top coating of paint film has an important role on resisting atmospheric materials of penetrating into under coating. However, chalking of top coating reduces its chemical performance as a steel coating. As a result, moisture such as rain water and acid stuffs such as SOx and NOx infiltrate the paint film easily and accelerate the paint film on deteriorating. Therefore, the paint film chalking is also evaluated.

\section{(2) Investigation data}

There are 542 bridges applying "A coating system " by which a mild corrosion environment is targeted and this accounts for $86.9 \%$ in 624 bridges of the total of the investigation bridge ac-

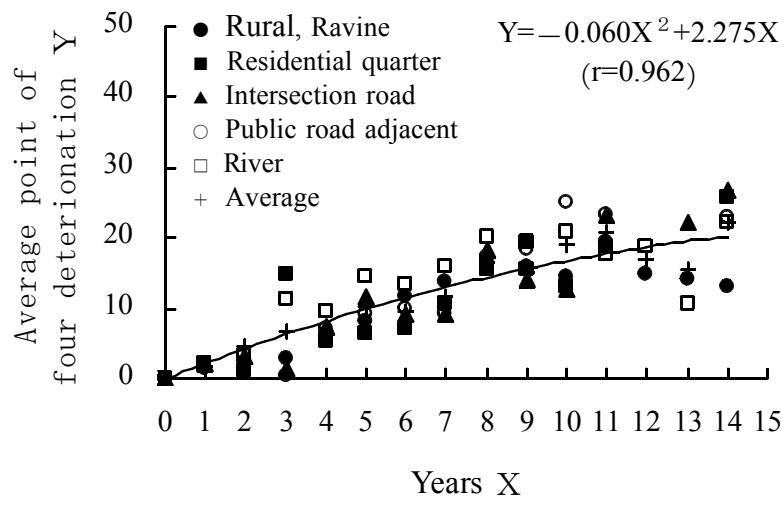

Fig. 1 Average Evaluation points according to the environment until 14 years.

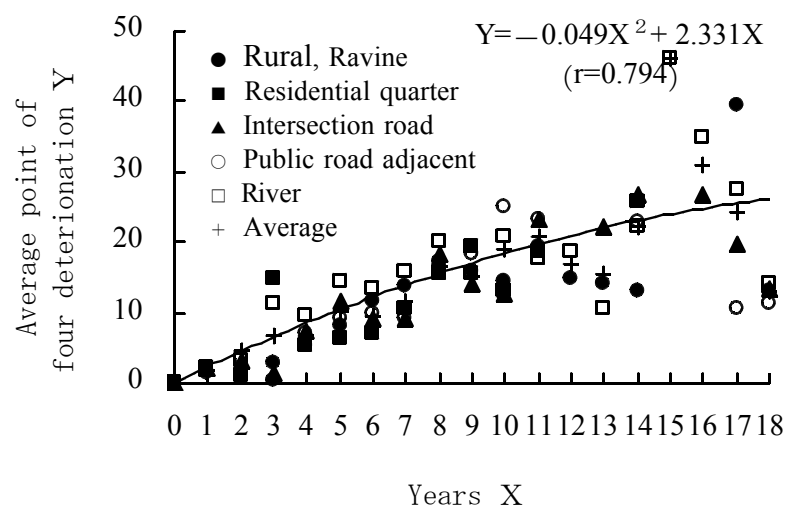

Fig. 2 Average Evaluation points according to environment (all period)

cordingto Table 1. Moreover, B coating system for factory zones and seashores is applied by 61 bridges (9.8\%) and C coating system exists by 21 bridges (3.3\%). These numbers are listed in Table 7.

As for the numbers of field investigation data, number of data inspecting " A coating system bridge " accounts for 63433, which becomes $87.9 \%$ of whole inspection data (72126) as shown in Table 7. 8693 (12.1\%) of the remainder are the inspection for B or C coating system. The compo- 
sition of this coating system is almost corresponding to current composition 7) of the steel bridge painting in Japan based on the research by Pubic Works Research Institute, Ministry of Public Works, Japan. In this paper, analyses are carried out mainly by the majority inspection data from A Coating System bridges. 63433 A coating system data shown in Table 7 is evaluated by four evaluation rates shown in Table 3 to Table 6 respectively and average rate and time from repainting was obtained in Fig. 1. The curve was an approximation one obtained by the following equation.

$$
\mathrm{Y}=\mathrm{a}_{2} \mathrm{X}^{2}+\mathrm{a}_{1} \mathrm{X}
$$

The approximation curve indicates the increasing rate of deterioration with respect to time from repainting throughout all environment. Correlation coefficient of Fig. 1 is computed as 0.962, which is considered to be very high because this data include all environments. However, evaluation results seem to disperse when inspection interval after repainting becomes long, especially after 15 years as shown in Fig. 2. Therefore, in this paper, inspection data up to the evaluation rate of 20 points (Fig. 1) and the data of the year up to 14 years are dealt.

\section{(3) Relationship between Paint film deteriora- tion and repainting time}

According to the investigation of repainting cycles for steel girder bridges, first repainting for newly constructed bridge is executed about 10 years after construction for all environments as shown in Fig. 3. Girder type steel bridge is the majority type of rating $87.3 \%$ in all types of steel bridges. According to the report published by Japan Railway Corporation ${ }^{8)}$ inspecting about 100 railway steel bridges, the repainting cycles of the paint film corresponding to A coating system of $\mathrm{JH}$ are about 10 years on the average.

In comparison with highway steel bridge and railway steel bridge, deteriorating process and characteristics are quite different even at the same corrosive environment due to their structural differences. Because highway steel bridges generally apply upper-deck type structure, steel members are covered by deck slabs. Therefore, ultraviolet rays are intercepted by deck, and internal girders are seldom affected by rain and snow falling from the air. Oppositely, a lot of pollution things such as dusts and salt adhere to the surface of inside girders because permeability worsens, and dewdrops are hard to evaporate. On the other hand, most of the railway steel bridges apply open floor type

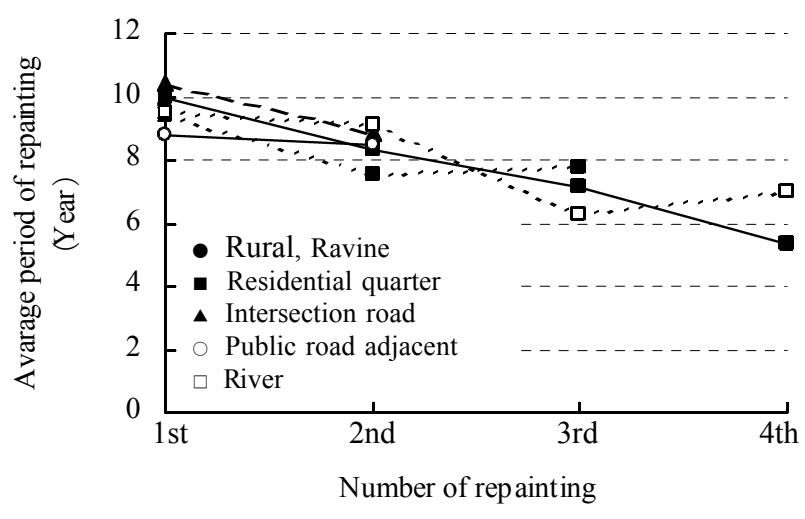

Data Number

\begin{tabular}{lrrrrr}
\hline \multirow{2}{*}{$\begin{array}{l}\text { Enviroments at } \\
\text { bridge location }\end{array}$} & \multicolumn{5}{c}{ Number of Repainting } \\
\cline { 2 - 6 } & 1st & 2nd & 3rd & 4th & Total \\
\hline Rural, Ravine & 114 & 25 & 2 & 1 & 142 \\
\hline Residential quarter & 43 & 19 & 4 & - & 66 \\
\hline Intersection road & 53 & 10 & - & - & 63 \\
\hline Public road adjacent & 36 & 6 & - & - & 42 \\
\hline River & 124 & 33 & 5 & 1 & 163 \\
\hline Total & 370 & 93 & 11 & 2 & 476 \\
\hline
\end{tabular}

Fig. 3 Average repainting period in terms of environment

Table 8 Correlation between each evaluation points

\begin{tabular}{|c|c|c|c|c|c|}
\hline & $\begin{array}{l}\text { Three det- } \\
\text { erioration }\end{array}$ & Rust & Peeling & Crack & Chalking \\
\hline $\begin{array}{l}\text { For det- } \\
\text { erioration }\end{array}$ & 0.997 & 0.991 & 0.928 & $\begin{array}{c}0.367 \\
(0.866) \\
\end{array}$ & 0.953 \\
\hline $\begin{array}{l}\text { Three det- } \\
\text { erioration }\end{array}$ & - & 0.993 & 0.938 & $\begin{array}{c}0.354 \\
(0.886) \\
\end{array}$ & 0.926 \\
\hline Rust & - & - & 0.894 & $\begin{array}{c}0.288 \\
(0.858)\end{array}$ & 0.926 \\
\hline Peeling & - & - & - & $\begin{array}{c}0.370 \\
(0.864) \\
\end{array}$ & 0.837 \\
\hline Crack & - & - & - & - & $\begin{array}{l}0.397 \\
(0.735) \\
\end{array}$ \\
\hline
\end{tabular}

Note) The total evaluation point of rust, peeling off, the crack, and the chalking is called four deterioration phenomenon. In ( ) is a correlation coefficient by the data until year 10 .

structure. Because of their porous and breathable structure, deterioration process and characteristics of railway steel bridges are quite different from those of highway steel bridges.

In spite of characteristic differences mentioned above, repainting cycles of highway steel bridges and railway steel bridges coincide around 10 years. Thus, atmospheric environment is thought to influence much more on repainting cycles than structural difference.

Moreover, repainting cycles of all environments 
tend to become shorter when the number of repainting increases as shown in Fig. 3. Defect of quality control concerning the foundation cleaning when repainting is found as a main cause of reducing repainting cycles according to our other study. Perfect extraction of deterioration area when inspection is impossible due to technical difficulties and inspection expenses. Certain rate of deteriorated paint film remains under the repainted coating. Thus, remaining pollutants and adhesive shortage accelerate the deterioration process.

\section{(4) Correlation coefficient between evaluation rates of four deterioration phenomenon}

The correlation coefficient between each paint film deterioration phenomena was shown in Table 8. Correlation between four deterioration phenomenon is found to be relatively high, and thus, each deterioration is found to influence each other closely as a result.

In this paper, " Paint film deterioration diagnostic system " is used to identify the deterioration degree of paint film as described in Chapter 1. This system can compute the area of three deterioration phenomenon such as rust, peeling off, and crack. As for the visual inspection, deterioration of the paint film is evaluated by four deteriorations (rust, peeling off, crack, and chalking) as described in Chapter 2.(1). However, the distinction between the chalking and the paint film deterioration is difficult in the image processing system. Therefore, the degree of paint film deterioration is evaluated by using three deterioration phenomenon (rusts, peels off, and crack) to exclude the chalking in "Paint film deterioration diagnostic system ".

The correlation coefficient between the evaluation rate sum of four deteriorations and that of three deteriorations is $\mathrm{r}=0.997$ which is comparatively high as indicated in Table 8. Therefore, the inspection with the sum of three deteriorations evaluation rates was found to be valid.

\section{(5) Characteristic of paint film deterioration} with respect to bridge types and locations

From Fig. 4 to Fig. 7, the relation between average evaluation point by three deterioration phenomenon and bridge age are plotted with respect to bridge types and locations.

From Fig. 4 and Fig. 5, a comparatively good correlation is found between the paint film deterioration and bridge age at the web member and at the bottom flange of the plate girder bridge. However, a remarkable disperse is found in the river environment.
This reason is not clarified completely, but following reasons are thought. The snow accumulated on the bridge is occasionally removed by simply pushed down to the river or by carried to thrown away with dump truck. Pushing down is the common removal method because of its efficiency and economy. Dump truck sometimes applied when water of the river is utilized for drink. Accumulated snow usually contains a lot of salt included in snow-melting agent, and this salt adheres to the girders and promotes paint film deterioration. Thus, the difference of snow removal methods influences on paint film deterioration.

Moreover, the bridge on the river tends to receive influence of moisture compared with other environments. The alkyd resin coating used for $\mathrm{A}$ coating system is soft and easily dissolved up by moisture. Therefore, the paint films swell by sucking dews. The paint films of bottom flange members are affected much more by dews than those of web members. However, even for the paint films of same lower flange members, influences are slightly different depending on heights from rivers and width of rivers. Thus, deterioration rate varies even at paint film of same lower flanges and tends to disperse.

Fig. 6 and Fig. 7 shows the relation between the paint film deterioration and bridge age at web members and bottom flange members of box girder bridges. As for the data of the rural environment and the intersection road and the public road adjacent environment, weak correlation is found. However, correlation cannot be found for river environment due to remarkable disperse. The cause of this disperse is thought to be induced by influence of the salt and dews as described in the example of plate girder bridges. The characteristics of deterioration for both bridge types might be obtained by evaluating the paint film deterioration as each bridge unit because the area ratio of web and bottom flange is structurally different for plate girder bridge and box girder bridge. However, further data accumulation is necessary because the data of the box girder bridge is about $10 \%$ compared with the data of plate girder bridge.

Plate girder bridges consist of webs, flanges, cross-frames and laterals. Moreover, these members are set up horizontally, vertically, diagonally and inclined. Fig. 8 shows the relationship between members of plate girder bridges and their repainting cycles with respect to surrounding environments. According to this figure, horizontal mem- 


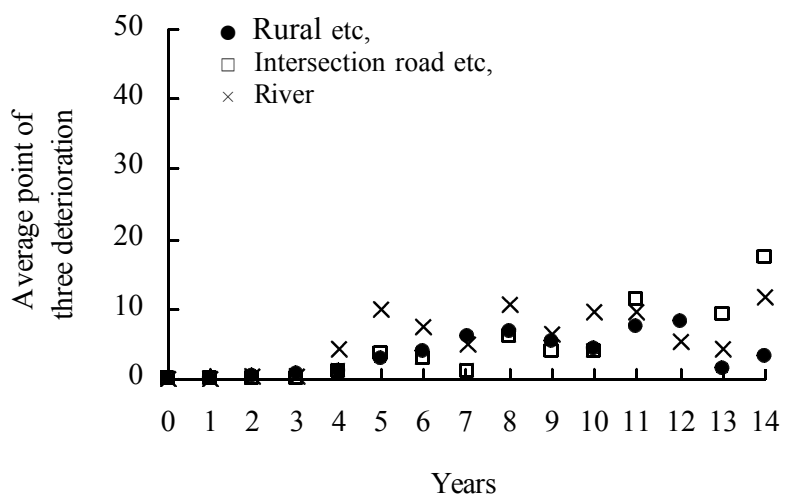

Fig. 4 Relationships between paint film deterioration and passing year (Plate girder bridge - Web plate)

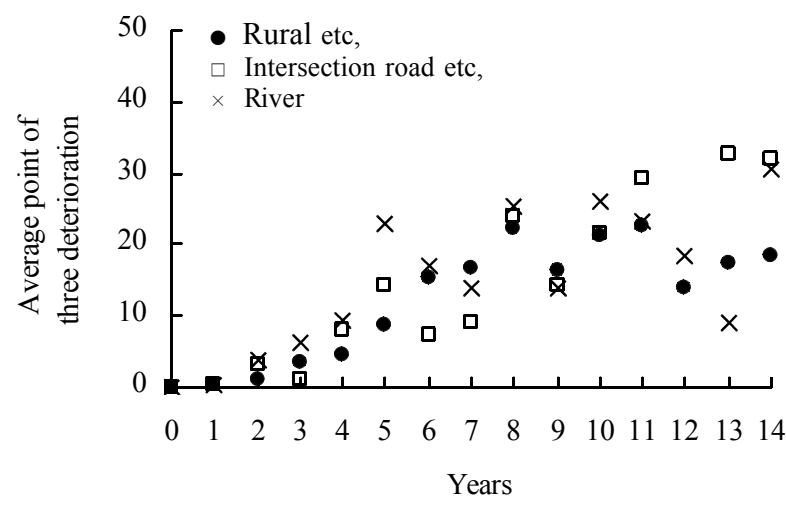

Fig. 6 Relationships between paint film deterioration and passing year (Box girder bridge - Web plate)

bers such as bottom flanges, laterals, and cross-frame deteriorate faster in each environment. On the contrary, the deterioration speed of the vertical members such as web is slow. In these horizontal materials, adhesions tend to accumulate such as chlorine from the sea, the sulfuric acid oxide and nitrogen oxide from automotive exhaust gas etc. Moreover, because the adhesions are located inside girders, rain cannot directly infiltrate and wash them. Moreover, the air located inside of the girders are not well ventilated and adhesion salinity is deliquescent, wet time of paint film surfaces lengthen and deterioration rate are accelerated compared with that of vertical members. Because lower flanges deteriorate quite faster than other members, one paint layer of the bottom flange is recently increased and repainting cycles are intended to be uniform within whole members of plate girder bridges.

(6) Relation between deterioration area and average deterioration grade

Fig. 9 shows the relation between average deterioration grade evaluating three deterioration

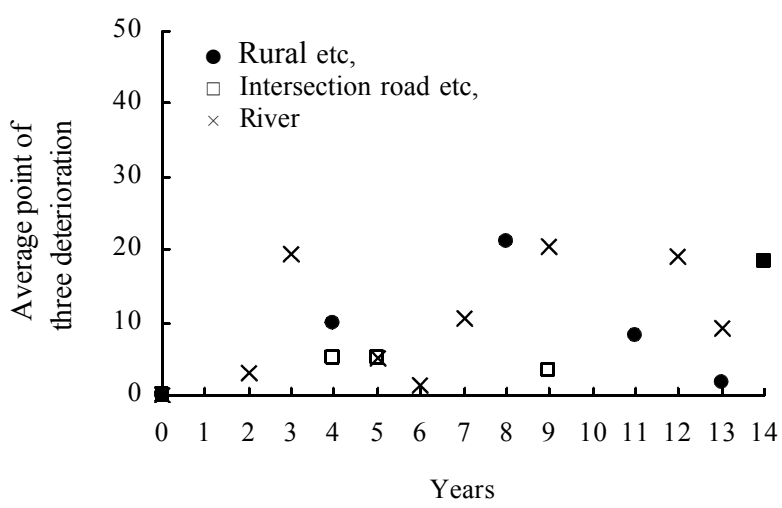

Fig. 5 Relationships between paint film deterioration and passing year (Plate girder bridge - Lower flange plate)

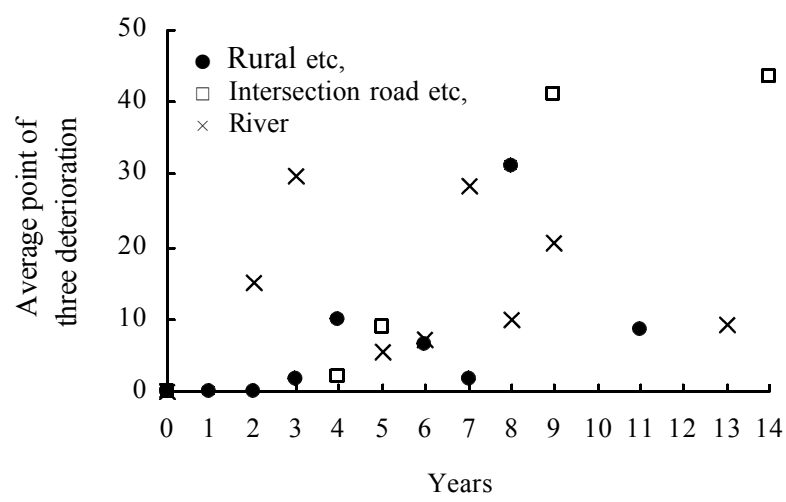

Fig. 7 Relationships between paint film deterioration and passing year (Box girder bridge - Lower flange plate)

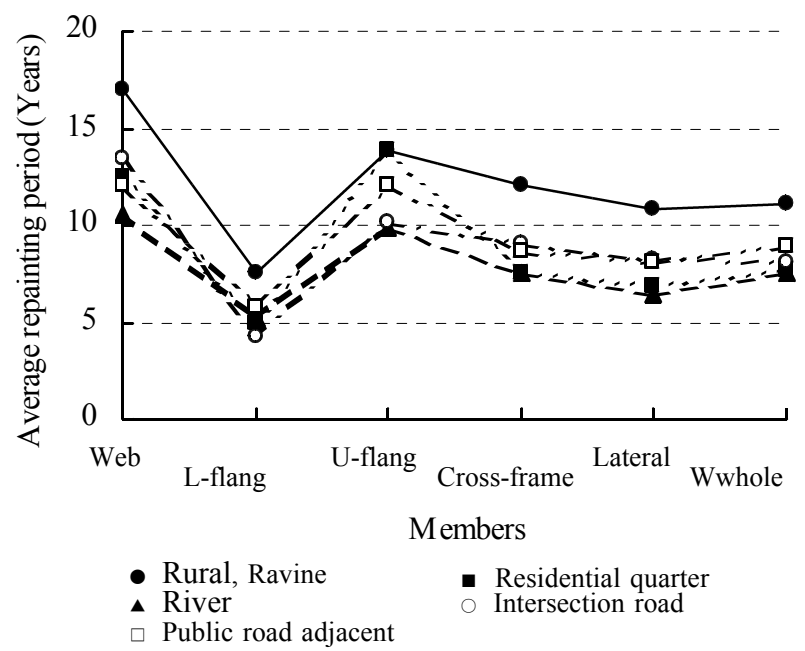

Fig. 8 Average repainting period of members (Plate girder bridge)

phenomenon (rust, peels, and cracks) and their deterioration area. Thus, very high correlation is confirmed in this graph. In the same manner, a good correlation is confirmed between average deterio- 
ration grade evaluating four deterioration phenomenon (rusts, peels off, cracks, and chalking) and their deterioration area from Fig. 10. Though steel bridge paintings are currently inspected by average deterioration grade evaluating four deterioration phenomenon (rusts, peels off, cracks, and chalking), inspection by deterioration area can substitute the former inspection method. Thus, was shown to have practical use that "Paint film deterioration degree diagnostic system " was confirmed to have practical ability to evaluate paint film deterioration by which the paint film deterioration degree is evaluated from total area of three deterioration phenomenon.

\section{RELATION BETWEEN EXTERNAL} DETERIORATION AREA AND CORROSION DEPTH UNDER PAINT FILM

Repainting the steel bridge paint film is executed by estimating the corrosion size and depth under the paint film (loss of steel cross section) from the external deterioration (deterioration on the paint film surface) on an experimental basis. However, the relation between external deterioration and corrosion under the paint film has not been clarified yet. Therefore, the relation was investigated with inspection data of actual bridges, the possibility to judge the repainting time adequately by estimating the steel corrosion under the paint film by heavy recurrence type was shown in 9).

The outline was described in this chapter and the relation between the external deterioration area rate and the corrosion depth was examined according to the data in 9).

\section{(1) The examined data}

\section{a) Investigated bridges}

Two bridges were selected from rural, urban, and coastal environment shown in Table 9.

\section{b) Extraction of sample}

From each bridge, 10 places were selected as samples. As for analysis, four grades established to divide deterioration degree. For each bridge, more than 2 samples were selected for each grade.

(1) Very slight deterioration: 1-2 point rust of about $1-2 \mathrm{~mm} \phi$ exists within every $100 \times$ $100 \mathrm{~mm}$

(2) Medium deterioration: 1-3 point rusts of more than $1-2 \mathrm{~mm} \phi$ exist in above-mentioned (1) condition

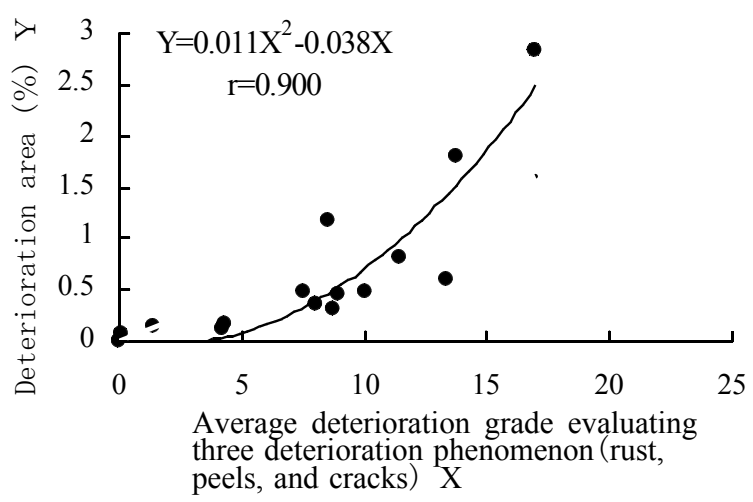

Fig. 9 Relationship between Average deterioration grade evaluating three deterioration phenomenon (rust, peels, and cracks) and their deterioration area

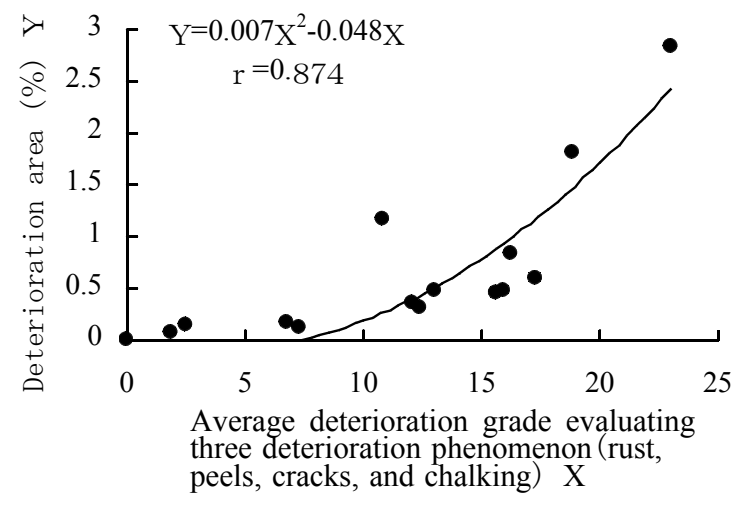

Fig. 10 Relationship between Average deterioration grade evaluating four deterioration phenomenon (rust, peels, cracks, and chalking) and their deterioration area

Table 9 Characteristics of investigated bridges

\begin{tabular}{lllll}
\hline $\begin{array}{l}\text { Environment } \\
\text { at Bridge } \\
\text { location }\end{array}$ & $\begin{array}{l}\text { Express } \\
\text {-way }\end{array}$ & $\begin{array}{c}\text { Bridge } \\
\text { completion }\end{array}$ & $\begin{array}{l}\text { Year of } \\
\text { paint used }\end{array}$ \\
\hline Rural & Tohoku & Omokawa & 1985 & A \\
\cline { 2 - 5 } & Chuo & Kofu Minami & 1972 & A \\
\hline Urban (H & $\begin{array}{l}\text { h traffic volum } \\
\text { Daisan Kreihin }\end{array}$ & Shisakai & 1976 & A \\
\cline { 2 - 5 } & $\begin{array}{l}\text { Yokohama Yo } \\
\text {-kosuka }\end{array}$ & Hino I.C. & 1979 & A \\
& Higashi Kanto & Futamata & 1981 & C \\
\cline { 2 - 5 } $\begin{array}{l}\text { Coastal } \\
\text { Seisho }\end{array}$ & Seishyo & Manhoh & 1985 & B \\
\hline
\end{tabular}

A) lead anticorrosive paint + alkyd resin paint

B) zinc-rich primer + chlorinated rubber paints

C) lead anticorrosive paint + phenolic resin type Micaceous Oxide paints + chlorinated rubber paints

(3) Considerable deterioration: 4-10 point rusts of more than $1-2 \mathrm{~mm} \phi$ exist in above-mentioned (1) condition

(4) Severe deterioration: Peeling off exist within above-mentioned (3) condition 


\section{c) Investigation item and measuring method}

The following three items of the extracted sample location on each bridge were measured.

(1) Measurement of paint film deterioration degree: Take a picture of the deterioration of the paint film and evaluate by "Paint film deterioration degree diagnostic system" ${ }^{3}$.

(2) Measurement of corrosion under paint film: After the stage of (1), paint film is removed. Then, a picture of corrosion under the paint film is taken and evaluated by the system.

(3) Measurement of corrosion depth under paint film: After the (2) stage, Silicon Resin is poured on steel surface and removed. Then, plaster is poured on the convex surface of Silicon Resin and removed. This plaster is the stuffing of corrosion surface. The corrosion section part of this stuffing is measured with an optical microscope (50 times) and the corrosion depth under the paint film is obtained.

\section{d) Comparison}

As for both external deteriorations and steel corrosion under paint film, the number of deteriorations, each size (diameter) of deteriorations, and total area of deteriorations were computed.

\section{(2) Relation between deterioration of being area rate and corrosion depth}

Fig. 11 shows the relation between the area of external deteriorations and area of steel corrosion beneath the paint film for 60-sample data. Regardless of bridge environment, the correlation was found to be very high as reported in Ref.9). Thus, corrosion under paint film can be well estimated by measuring external deterioration.

Fig. 12 shows the relation between passing year and the corrosion depth for each selected bridge. According to Fig. 12, the relation between passing year and the corrosion depth is not especially recognized and the maximum value of the corrosion depth is $0.25 \mathrm{~mm}$. The relation between the corrosion environment and the corrosion depth is not especially found. As for this reason, the corrosion depth of steel bridge was thought not to increase more than some amount regardless of the corrosion environment and passing year when inspection is conducted regularly based on the manual and regular repainting are repeated.

Fig. 13 shows the relation between corrosion depth and external deterioration area. Most of the

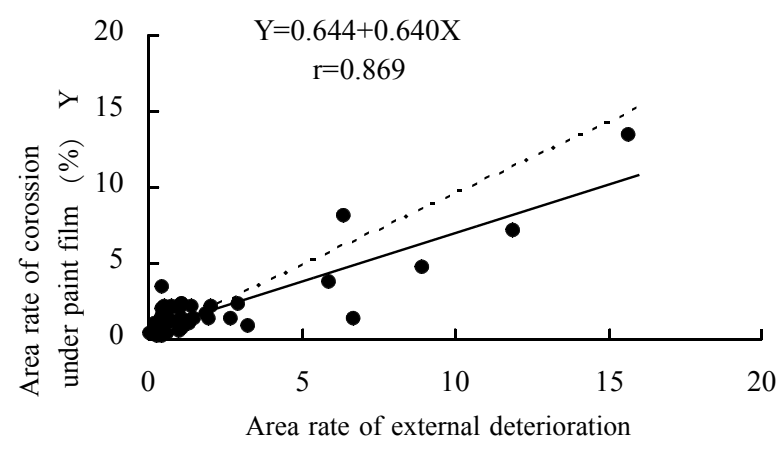

Fig. 11 Area rate of external deteriorations and corrosions

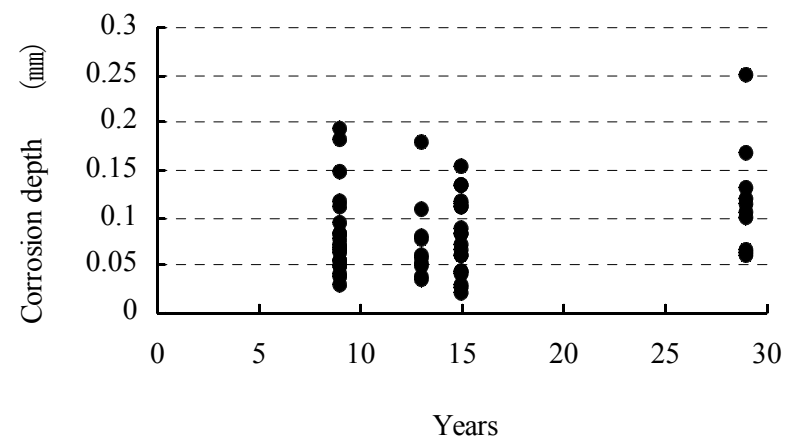

9 year : KofuMinami (Rural), Manjoh (Coastal)
13 year : Futamata (Coastal)
15 year : Omokawa (Rural), Hino I.C. (Urban)
29 year : Shisakai (Urban)

Fig. 12 Corrosion depth and time from construction

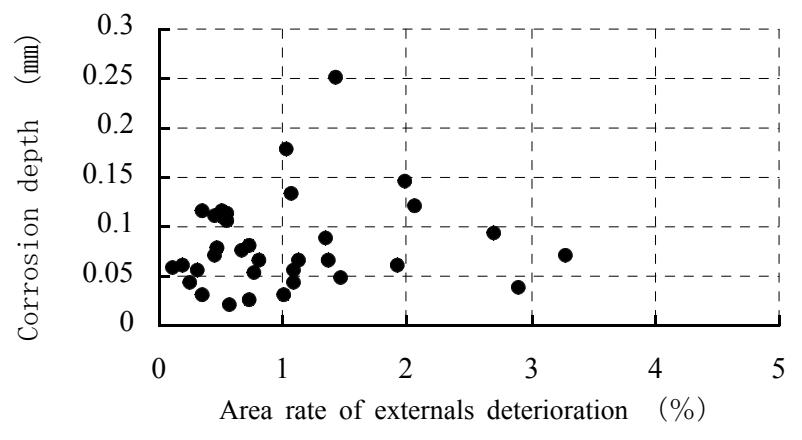

Fig. 13 Relation between corrosion depth and externals deterioration area rate

plotted data is located within the range of $0.2 \mathrm{~mm}$ of corrosion depth and 3\% of deterioration area. Therefore, when repainting is conducted regularly within less than $3 \%$ of external deterioration area, corrosion depth is thought to reaches as much as about $0.20 \mathrm{~mm}$. 
Table 10 Outline of the examined data

\begin{tabular}{|c|c|c|c|c|}
\hline Kind of data & $\begin{array}{c}\text { Outdoor exposure test } \\
\text { and Date number }\end{array}$ & $\begin{array}{c}\text { Environment at the } \\
\text { Bridge location }\end{array}$ & $\begin{array}{c}\text { Exposure period } \\
\text { (Years) }\end{array}$ & $\begin{array}{l}\text { Measurement method } \\
\text { Area rate of deterioration }\end{array}$ \\
\hline Inspection & 624Bridge (63433 date) & Mild & $1 \sim 18$ & $\begin{array}{l}\text { visual comparison with } \\
\text { SSPC Standard Charts }\end{array}$ \\
\hline Painting test panel & $\begin{array}{l}\text { Tokyo (Machida) } \\
\text { Hokuriku (Oyashirazu) } \\
\text { Okinawa (Kyoda) } \\
\qquad \text { (Each } 1 \text { date) }\end{array}$ & $\begin{array}{l}\text { Mild } \\
\text { Salinity coming flying } \\
\text { High temperature humidity }\end{array}$ & $1 \sim 6$ & $\begin{array}{l}\text { Fixed quantity by using } \\
\text { the grayscale morphology }\end{array}$ \\
\hline Specific Inspection & $\begin{array}{l}\text { Jobandou expressway } \\
\text { 21Bridge (239 date) }\end{array}$ & Mild & $4 \sim 15$ & method \\
\hline
\end{tabular}

\section{LIFE CYCLE ESTIMATION OF PAINT FILM}

Energy of ultraviolet rays decomposes paint film and promotes deterioration. Thus, layer of paint film is consumed. ${ }^{10)}$ Therefore, if the surface fracture velocity of paint film caused by optical oxidation and the diffusion speed of water and oxygen into paint film are obtained, life cycle estimation of paint film could be possible. However, because steel bridge paintings are exposed in the air and wet and dry conditions are repeated irregularly due to rain and dew, deterioration process is quite difficult to be approximated by ideal expression. Therefore, life cycle of paint film is investigated by analyzing actual bridge deterioration statistically. In this chapter, estimation curve of paint film deterioration is assumed from actual inspection data statistically, and practical use of the estimation curve is studied.

\section{(1) The examination data of paint film deterio- ration curve}

Three data were applied to obtain approximation curve such as (a) inspection data of actual bridges, (b) exposure test data by painted steel specimen, and (c) specific investigation data of actual bridges. Outlines of these data are described in Table 10.

\section{a) Inspection data of actual bridges}

63433 data inspected for steel bridges of A coating system was computed among the whole field inspection data shown in Chapter 2. The deterioration area rate was obtained by inspection experts comparing photos and the standard chart ${ }^{6)}$. b) Exposure test data by painted steel specimen

Painting methods and exposure methods for steel specimens were already reported in another
Table 11 Real bridge for paint film deterioration measurement

\begin{tabular}{|c|c|c|c|c|}
\hline № & Bridge & Interchange Brid & ge type & Passing year \\
\hline 1 & Soka & $\begin{array}{l}\text { Soka } \sim \text { Misato } \\
\text { Nishi }\end{array}$ & P.G. & 9 months, 4 \\
\hline 2 & Nakathuma & \multirow{3}{*}{$\begin{array}{l}\text { Kita Ibaragi } \\
\sim \text { Iwaki }\end{array}$} & P.G. & $4 \mathrm{mo}$ \\
\hline 3 & Kanazonogawa & & B.G. & $6 \mathrm{mo}$ \\
\hline 4 & Satonegawa & & P.G. & $6 \mathrm{mo}$ \\
\hline 5 & Hananuki & $\begin{array}{l}\text { Hitathi Kita } \\
\sim \text { Takahagi }\end{array}$ & P.G. & 9 months, 9 \\
\hline 6 & Nakagou & \multirow{2}{*}{$\begin{array}{l}\text { Takahagu } \\
\sim \text { Kita Ibaragi }\end{array}$} & P.G. & $9 \mathrm{mo}$ \\
\hline 7 & Okitagara & & P.G. & $9 \mathrm{mo}$ \\
\hline & Tajiri & \multirow{3}{*}{$\begin{array}{l}\text { Hitachi Minami } \\
\text { Ota } \\
\sim \text { Hitachi Kita }\end{array}$} & P.G. & ths, 11 \\
\hline & Omori Va. (B) & & P.G. & ths, 11 \\
\hline 10 & Miyatagawa & & $\begin{array}{l}\text { Tuss' } \\
\text { P.G. }\end{array}$ & $8 \mathrm{~m}$ \\
\hline 11 & Edogawa & \multirow{2}{*}{$\begin{array}{l}\text { Misato T.B. } \\
\sim \text { Nagareyama }\end{array}$} & B.G. & 12 \\
\hline 12 & Imajohgawa & & P.G. & 12 \\
\hline 13 & Momiyagawa & $\begin{array}{l}\text { Hitachi Minami } \\
\text { Ota } \\
\sim \text { Hitachi Kita }\end{array}$ & P.G. & 12 \\
\hline 14 & Obagawa & $\begin{array}{l}\text { Misato T.B. } \\
\sim \text { Nagareyama }\end{array}$ & P.G. & 13 \\
\hline 15 & Misato & \multirow{2}{*}{$\begin{array}{l}\text { Misato } \\
\sim \text { Misato T.B. }\end{array}$} & P.G. & 13 \\
\hline 16 & Misato I.C. & & P.G. & 13 \\
\hline & Omori (A) & \multirow{2}{*}{$\begin{array}{l}\text { Hitachi Minami } \\
\text { Ota } \\
\sim \text { Hitachi Kita }\end{array}$} & P.G. & nths, 13 \\
\hline & Omori (B) & & P.G. & 11 months, 13 \\
\hline 19 & Kujigawa & $\begin{array}{l}\text { Naka } \sim \text { Hitachi } \\
\text { Minami Ota }\end{array}$ & P.G. & 14 \\
\hline 20 & Omori Va. (A) & $\begin{array}{l}\text { Hitachi Minami } \\
\text { Ota } \\
\sim \text { Hitachi Kita }\end{array}$ & P.G. & 4 months, 14 \\
\hline & Nakagawa & Mito $\sim$ Naka & P.G. & 15 \\
\hline
\end{tabular}

note) Investigated points are web surface.

P.G. Means Plate Girder, B.G. means Box Girder and $\mathrm{T}$ means Truss.

paper ${ }^{11)}$. The data of painted specimens was decided to be handled as that of bottom flange because they were exposed horizontally.

\section{c) Specific investigation data of actual bridges}

21 bridges of A-type coating system located in the Joban Expressway were selected. These bridges 
shown in Table $\mathbf{1 1}$ have not received repainting from construction. Because investigation of paint film deterioration on the same bridge needs quite long years, bridge investigation data from same environment are considered as that of same bridge.

Though painting methods and exposure conditions are not exactly same even in the same environment, investigation data are considered same for statistical computation.

\section{(2) Examination of paint film deterioration curve}

In order to estimate life cycle of paint film, the recurrence type and the growth curve, etc. have been studies 12) $\sim 15$ ). Both of the estimation curves were studied to estimate deterioration from beginning of deterioration until complete deterioration. Complete deterioration means the state that whole of steel surface is covered by corrosion. However, the bridge is actually repainted with the deterioration area rate of about $0.2-5 \%$. Therefore, in order to judge adequate time of repainting for bridge safety and economically, deterioration curve of the deterioration beginning should be clarified specifically. Moreover, in order to obtain deterioration curve until repainting, complex recurrence type and growth line estimation are not necessary which requires a lot of parameters and complex analysis. Therefore, the deterioration curve of the paint film decided to be obtained by using the second curve in this research.

Inspection data shown in Table $\mathbf{1 0}$ was examined its adaptability to be approximated by second curve and verified for each environment and each members. Though second curve cannot represent S-shape curve which gradient is plus at the beginning and then gradient becomes minus, exposure time of 10 to 20 years for repainting is considered short enough to be approximated by second curves.

\section{(3) Remaining Life Estimation Curve for paint film}

In order to estimate remaining life of paint film, it must be defined clearly. However, range of remaining life of paint film is difficult to define clearly. Deterioration condition to be repainted is different according to road administrations. Moreover, deterioration condition of painting differs depend on environment and maintenance. Therefore, judgment of repaint has left to painting experts. In this paper, following definitions are assumed considering repainting execution in $\mathrm{JH}$.

(1) A-Coating System is selected for this study. (rust resisting paint/oily alkyd resin coating system) A-Coating System is mainly used in a mild environment.

(2) Total deterioration area of three phenomenon (rusts, peels off, and cracks) are used for estimating life cycle of paint film

(3) Life cycle estimation is conducted for each environment

(4) Life cycle is estimated based on deterioration estimation curve obtained from actual inspection data

All the paint film deterioration curves obtained by 4.(2) are shown in Fig. 14. The deterioration curves can be roughly divided into three (1) salinity adhering environment (Hokuriku), (2) high temperature humidity environment (Okinawa), and other (3) mild environments) according to Fig. 14.

Eight paint film deterioration curves classified as a mild environment (Fig. 14) are enlarged in Fig. 15. At the deterioration area rate of year 15, a minimum value is about $0.5 \%$ in the web (intersection road etc.) and the maximum value is about $7 \%$ in the bottom flange (intersection road etc.). However, the deterioration tendency of these eight curves is almost corresponding. Moreover, the deterioration area rate of the bottom flange (all environments) and the painting test panels (Tokyo) is large and the deterioration area rate of the web (all environments) is small.

As described in Chapter 2 (5), this is caused by structural difference between horizontal members and vertical members.

As for mild environment, deterioration estimation curve for bottom flange and web might be considered separately. However, influence on deterioration rate of environment was confirmed to be much larger than bridge type and bridge members in 2. (5). In addition, considering data deviation caused by visual observation, estimating remaining life separately in mild environment is thought not to be rational at present stage. In the future, after the accumulation of the quantitative data by the image processing system, reexamination of estimation curves can be possible. In addition, $20 \%$ of the bridges used in this analysis have already received repainting of more than 2 times. Therefore, quality control in repainting works should also be clarified before exact estimation.

3 deterioration estimation curves classified by environment are drawn on Fig. 16 and the parameters of each curve are shown in Table 12. 95\% trust threshold value curve of an upper and lower limit is shown in each curve. 


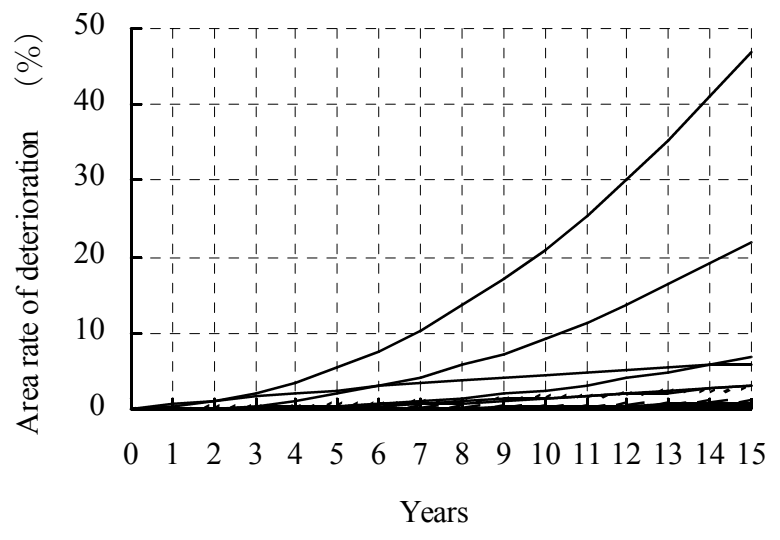

$\leftarrow$ Painting Test Panel Date (Hokuriku)

$\leftarrow$ Painting Test Panel Date (Okinawa)

Lower flange (Intersection road)

Lower flange (River)

$\leftarrow$ Lower flange (Rural)

Painting Test Panel Date (Tokyo)

Web (River)

$\left.\begin{array}{l}\text { Web (River) } \\ \begin{array}{l}\text { Real bridge investigation Date (Web) } \\ \text { Web (Rural) }\end{array}\end{array}\right\} \begin{gathered}\text { Reference } \\ \text { Fig. 15 }\end{gathered}$

Web (Intersection road)

Fig. 14 Paint film deterioration curve (each part and each environment)
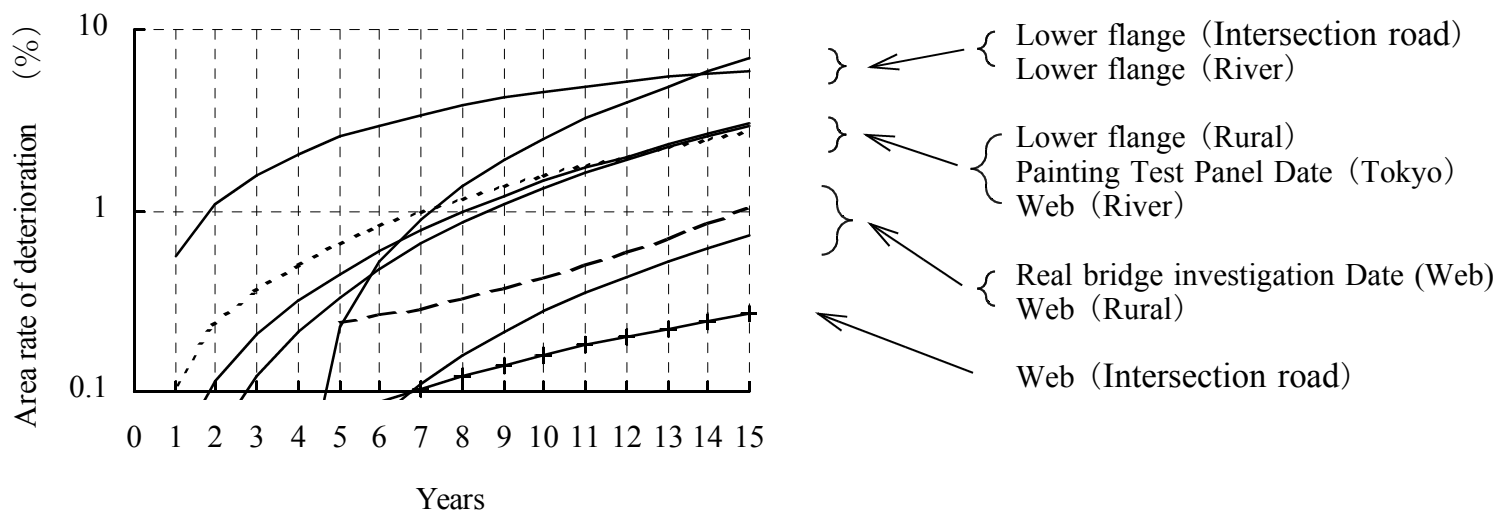

Fig. 15 Paint film deterioration curve (display of logarithm of Fig. 14)

Table 12 Parameters for Life Cycle estimation curves

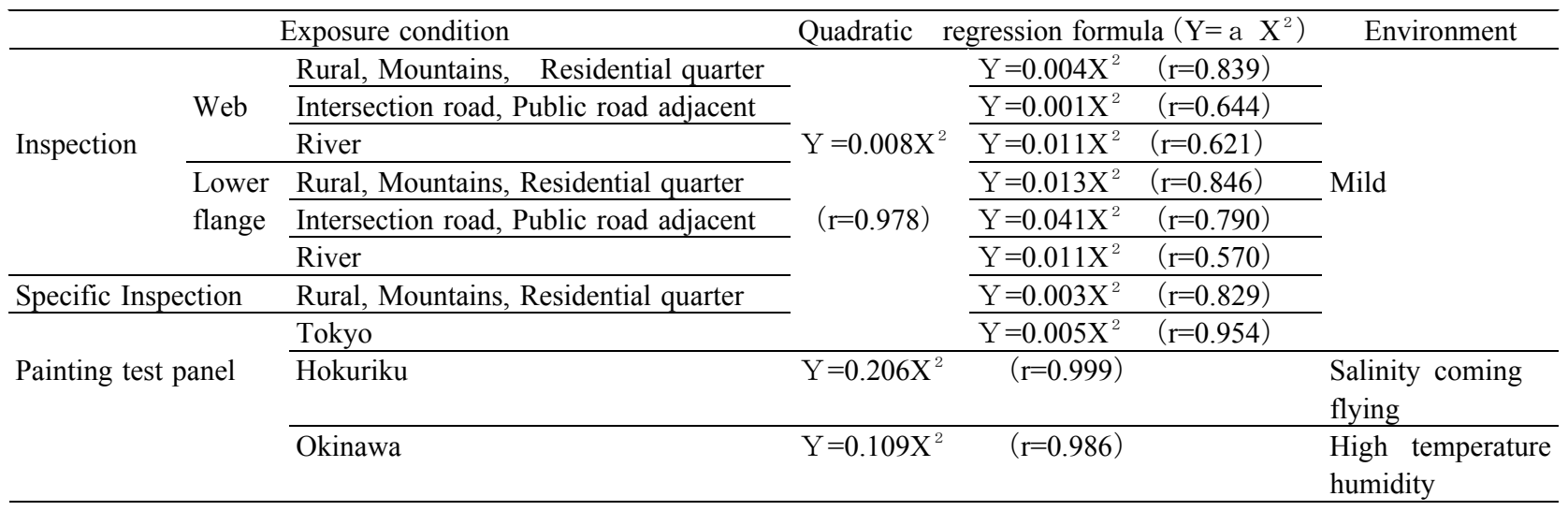

note) Y: Deterioration area rate and X: Passing year's r: Correlation coefficient with measurement value

\section{JUDGMENT OF REPAINTING TIME}

As mentioned before, definition of paint film life cycle is vague. As for this reason, Yoshida 12) enumerates three following reasons, that is (1) There are a lot of causes accelerating deterioration. (2) Environment and quality control of painting work is not uniform. (3) Limit state of paint film (the end of paint film life cycle) is not clear. In order to define life cycle of paint film, these problems must be clarified clearly.

In chapter 2, (1) and (2) has already been investigated by analyzing huge field inspection data statistically. However, there is no concrete solution 


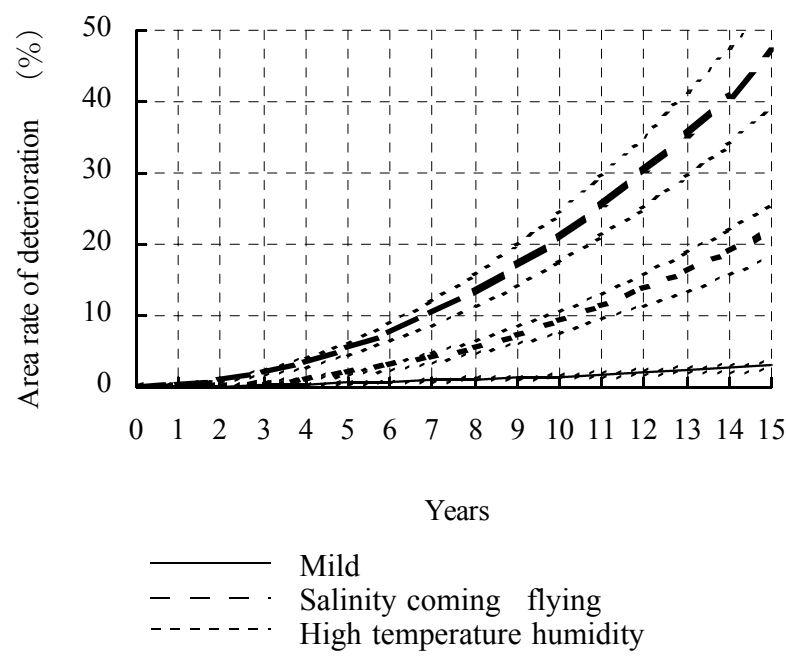

Fig. 16 Life Cycle estimation curves

Table 13 Parameter of straight line recurrence type

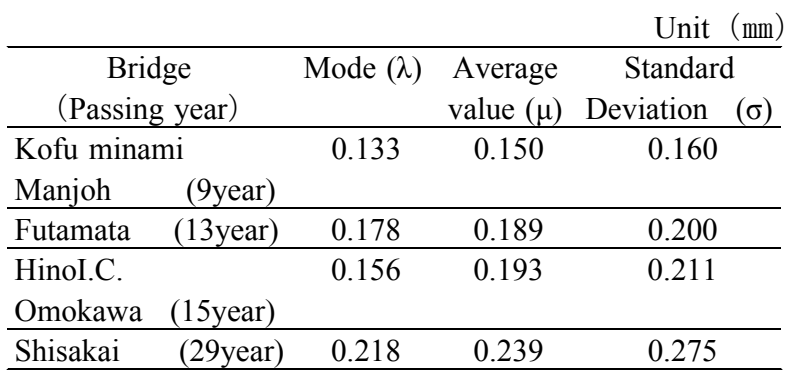

for (3). Thus, even if paint film deterioration area ratio can be estimated by statistic curves, suitable (economical and safe) repainting time cannot be obtained. Therefore, in this research, life cycle of paint film was assumed as practical result of repainted cycles conducted for steel bridges in $\mathrm{JH}$. Estimation of paint film life cycle was investigated by analyzing the relation between deterioration area ratio on the surface and corrosion depth under the paint film described in chapter 3 .

\section{(1) Distribution of the maximum corrosion depth}

The 60 data of six bridges shown in Table 9 in Chapter 3 was used for the examination. Here, the maximum values of corrosion depth were selected and cumulative probability of maximum corrosion depth was drawn on Fig. 17. Frequency value $(\lambda)$, average value $(\mu)$, and standard deviation ( $\sigma)$ obtained from each recurrence curve are shown in Table 13.

Nextly, estimation line of the maximum corrosion depth with respect to time was drawn on Fig. 18 from the distribution of the maximum corrosion depth.

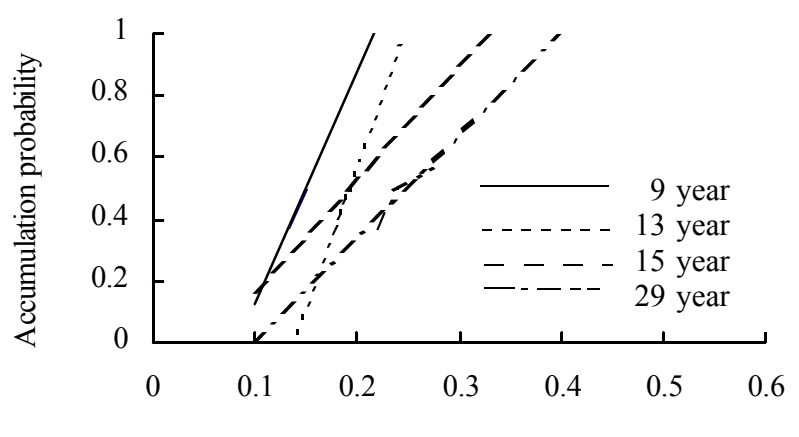

Max corrosion depth (mm)

Fig. 17 Distribution of the maximum depth

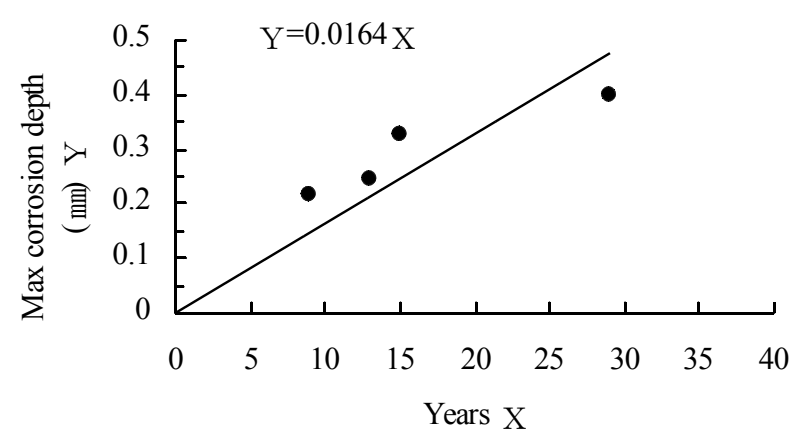

Fig. 18 Forecast of the maximum depth

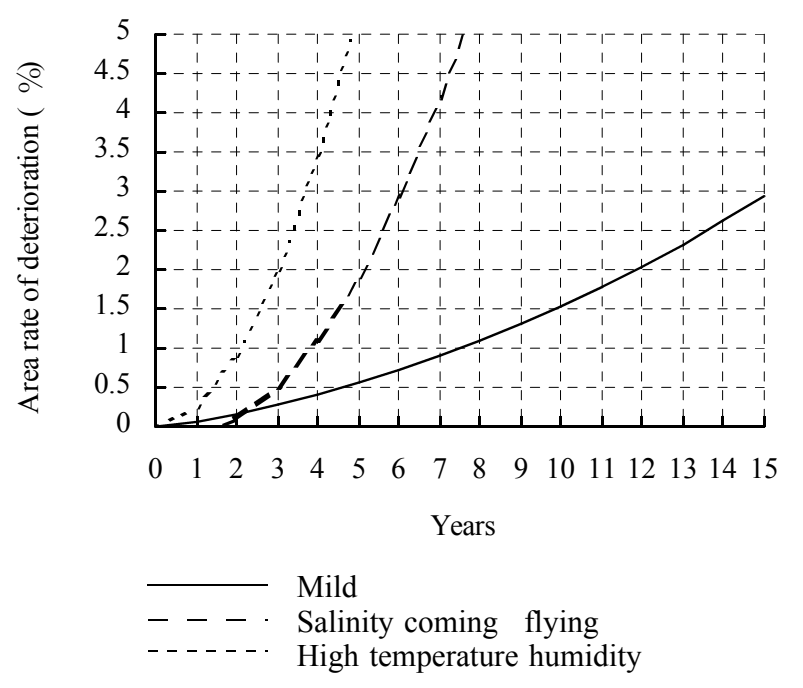

Fig. 19 Life Cycle Estimation curves

(Enlarged Figure of Fig. 16)

The maximum corrosion depth was found to increase linearly by $0.02 \mathrm{~mm} /$ year according to Fig. 18. (straight line recurrence type $Y=0.0164 X, Y$ : maximum corrosion depth and $\mathrm{X}$ : passing year). This result coincided with common idea that the corrosion speed of the steel material was generally $0.02 \mathrm{~mm} /$ year. In Fig.18, maximum corrosion depth was found as $0.2 \mathrm{~mm}$ after ten years from painting (Average repainting time for A painting system) . 


\section{(2) Life cycle and repainting time of paint film}

$95 \%$ of the whole data is included within the range of the external deterioration area rate 3\% and corrosion depth of $0.20 \mathrm{~mm}$ according to Fig. 13 in Chapter 3. Moreover, the relation between passing year and the corrosion depth is not especially found according to Fig. $\mathbf{1 2}$ and the highest value of the corrosion depth is $0.25 \mathrm{~mm}$. The relation between the corrosion environment and the corrosion depth is also not especially admitted as described in 2(2). Therefore, deterioration area ratio of $3 \%$ is estimated to correspond to corrosion depth of $0.20 \mathrm{~mm}$ under the paint film.

Fig. 19 is an enlarged figure of Fig. 16 from the deterioration area rate of $0 \%$ to $5 \%$. The repainting time in each environment corresponding to deterioration area of 3\% is presumed from Fig. 9 as follows, mild environment: 15 years, high temperature humidity environment: 6 years, salinity adhering environment: 4 years. This result had just corresponded to the past investigation results ${ }^{2)}$.

\section{TO THE END}

After the current technical problems of steel bridge (steel highway bridge) painting were clarified, a quantitative evaluation of the paint film deterioration and the possibility of the life cycle estimation of paint film were examined in Ref.16).

This paper focused on estimating the deterioration process and speed by analyzing field inspection data statistically, and final target was to obtain life cycle of paint film. Physical and chemical mechanism of paint film deterioration was not specifically described in this paper. However, because chemical clarification of deterioration process cannot be ignored for effective maintenance of steel bridges, development of diagnosis system for paint film deterioration is urgently required. Therefore, future subject must be to carry out rational analysis of huge inspection data and to find parameters for life cycle estimation.

In this paper, only A coating system applied for mild corrosion environment has been investigated. Heavy-duty coating system has not been investigated because example bridges and painted specimens were too young to deteriorate and number of examples was few. Data accumulation and widening investigation on other coating systems must be required in the future.
ACKNOWLEDGMENT : In settling this research I received the guidance of Professor Yozo Fujino (Department of Civil Engineering, Graduate School of Engineering, Tokyo University), and Professor Shigeo Tsujikawa (Department of Metallurgy, Graduate School of Engineering, Tokyo University). I deeply express my gratitude.

\section{REFERENCES}

1) Katawaki, $\mathrm{K}$ : Bridge and Painting, Japan Association of Steel Bridge Painting Contractions, 1996.

2) Mathuda, T., Fujiwara, H., Sakuma, T. : Actual Condition Survey of Steel Bridge Painting, Steel Bridge Painting, Vol.18, No. 4, pp.27-37, 1990.4.

3) Fujiwara, H.,Miyake, M., Akai, T., Kono, Y., Degawa, S : Study on Evaluation Method for Paint Film Deterioration on Steel Bridge with Image processing Technology, J.Struct, Mech, Earthquake Eng., Proc. JSCE, No. .598/ I -44, pp.85-96, 1998.7.

4) Japan Highway Public Corporation : Procedure for Maintenance and Repair, Steel Bridge Painting, May 1988.

5) Japanese Society of Construction : Manual for the Investigation of Paint Films on Steel Bridges, Proc. JSSC, Vol.18, No. 18, pp.43-60, 1982.10.

6) ASTM, Standard Method of Evaluating Degree of Rusting on Painted Steel Surface. D-610-95, (Steel Structures Paint Council. SSPC-Vis-2).

7) Katawaki, K : History and Development of the Painting of the Highway Bridge, Steel Bridge Painting, Vol.23, No. 1, pp.51-63, 1996.

8) Kirimura, K., Enari, T : Study regarding the Durability of the Painting Film in the Steel Railroad Bridge, Shikizai, Vol.66, No. 12, pp.730-735, 1993.

9) Fujiwara, H.,Sugano, T. : Research into The Correlation between The Deterioration of The Paint Film on Steel Bridges and The Corrosion Occurring beneath The paint Film, J. Struct, Mech, Earthquake Eng., Proc. JSCE, No. 537/ I -35, pp.167-181, 1996.4.

10) Sugano, $T$ : Corrosion Control Painting of The Steel Bridge, IHI Tecnical Note, S.Vol.6, pp.17-24, 1982.

11) Fujiwara, H., Tahara, $Y$ : Reserch on Heavy Duty Anti-Corrosive Painting Applied to Newly-Built Steel Bridge of Expressways, J.Struct, Mech, Earthquake Eng., Proc. JSCE, №..563/ I -39, pp.23-34, 1997.4.

12) Yoshida, T. :Service Life of Paint Films [1], Shikizai, Vol.65, No.5, pp.308-316, 1992.

13) Yoshida, T. : Service Life of Paint Films [2], Shikizai, Vol.65, No.6, pp.364-377, 1992.

14) Yoshida, T. : Service Life of Paint Films [3], Shikizai, Vol.65, No.7, pp.435-440, 1992.

15) Yoshida, T. : Service Life of Paint Films [4], Shikizai, Vol.65, No.8, pp.500-510, 1992.

16) Fujiwara, H. : Quantitative Analysis on Deterioration and Remaining Life of Steel Bridge Painting Based on Field Data, The Tokyo University doctorate thesis, 2000.9.

(Received November 28,2002) 